Indonesian Journal of EFL and Linguistics

Vol. 6 No. 1, 2021

eISSN: 2503-4197, pISSN: 2527-5070

www. indonesian-efl-journal.org

doi: http://dx.doi.org/10.21462/ijefl.v6i1.395

\title{
Investigating Ideological Factors in Family Language Policy
}

\author{
Rani Septi Sapriati \\ Sriwijaya University \\ e-mail: sapriatiranisepti@pps.unsri.ac.id \\ Soni Mirizon (Corrresponding Author) \\ Sriwijaya University \\ e-mail: smirizon@unsri.ac.id \\ Sary Silvhiany \\ Sriwijaya University \\ e-mail: ssilvhiany@unsri.ac.id
}

\begin{abstract}
:
A family has a role in supporting bilingual or multilingual children. In acquiring English for instance, family language policy is likely to shape the development of children bilingualism or multilingualism. Through a qualitative study in a case study design, the language ideologies of two bi-/multilingual families in Palembang were investigated and explored. The participants of this study were the Zahra and the Najwa families who brought up their children in more than one language including English. The data were collected through ethnographic interviews with the parents, grandmother, and children. Thematic analysis was used in analyzing the data of this study. The raw data were coded and classified into categories to derive big major themes regarding ideological factors that shaped language policy. The derived themes were then interpreted descriptively. The results indicated that there were some ideological factors found that contributed to the shaping of the language policy of those two families, such as social values, economical values, political values, cultural values, parents' knowledge toward language acquisition, and bi-
\end{abstract}


Rani Septi Sapriati, et al

/multilingualism. The findings of this study suggest that families need to provide support for their children in their bilingual or multilingual journey. Furthermore, stakeholders and professionals should play a role in the choice of language used in education as well as provide considerable support and assistance for language policy in family domain.

Keywords: Bi-/multilingualism, family language policy, language ideologies

\section{INTRODUCTION}

It is undeniable that most people use English nowadays as 1.35 billion people in the world are speaking English either as the native language, a second or foreign language in 2021 (Szmigiera, 2021). It emphasizes that, in regards to national and ethnic languages, the use of English is popular in the globalization era. As a consequence, bi-/multilingualism appear almost in the entire nation in the world. Indonesia is indeed one of the world's multilingual countries, with more than seven hundred languages (Romaine, 2013). However, unlike many other countries such as India, Malaysia, and the Philippines where English is their second language (Simpson, 2007), it functions as a foreign language in Indonesia.

In terms of the ability to practice over one language, certainly least English, promoting bi-/multilingualism in the household can indeed be obtained by upholding a language policy. The Family Language Policy (FLP) is generally described as how members of the family choose which languages to be practiced at home, and it is initiated and discontinued by themselves (Caldas, 2012; King et. al, 2008; Spolsky, 2004). According to Spolsky (2004), language policy includes language ideology/beliefs, language practice, and management. Language ideology has been the most critical of these components since it functions as the core principle for shaping and enforcing the other elements of language policy; it contains the beliefs and statuses of languages that individuals carry (Spolsky, 2004). In terms of the family context, it has an impact on parental involvement in home literacy activities and management.

Some previous related studies concerned with family language policy. They particularly focused on exploring family language ideologies guided by Spolsky's (2004) language policy model. They were taken in different contexts such as immigrant, migrant, transnational, and multilingual families in a multilingual country. In immigrant context, it involved Russian-speaking immigrant families in Israel (Moin et al., 2013), Scottish Chinese families (Bell, 2013), Turkish families in the Netherlands (Bezcioglu-Goktolga \& Yagmur, 2018), Libyan immigrant family in the U.S (Yazan \& Ali, 2018), and Chinese immigrant families in Quebec (Curdt- 
Christiansen, 2009). Furthermore, in the migrant context, there were Greek families in Luxembourg (Gogonas \& Kirsch, 2018) and Spanish-speaking migrants to New Zealand (Berardi-Wiltshire, 2017). Also, there were transnational multilingual families in Colombia (Soler \& Zabrodskaja, 2017), and multilingual families in China (Curdt-Christiansen \& Wang, 2018).

These previous related studies indicate that social, cultural, political, economic values, parental aspirations, and parental bilingualism knowledge and experience all play a huge role in guiding their uses of language. In relation to the cultural values, some immigrant families recognized that bringing bi-/multilingual children with only heritage language at home was an attempt to maintain their identity, culture, religions, and origins (Bell, 2013; Bezcioglu-Goktolga \& Yagmur, 2018; Moin et al., 2013; Yazan \& Ali, 2018). Furthermore, being bi-/multilingual will enhance their self-esteem (Bell, 2013) and connect to people in society and education (Moin et al., 2013). Another studies on multilingual families found that English is valued highly; it is quite related to citizenship and the global market (Gogonas \& Kirsch, 2018; Yazan \& Ali, 2018). It is also known as an international language which is important to master in order to reach better future life, get high salaries and incomes as well as obtain a high-paid job or good career (Berardi-Wiltshire, 2017; BezciogluGoktolga \& Yagmur, 2018; Curdt-Christiansen \& Wang, 2018; Gogonas \& Kirsch, 2018; Yazan \& Ali, 2018). Bi-/multilingual children are hoped to have a chance to study abroad (Curdt-Christiansen \& Wang, 2018) and participate in the educational system (Gogonas \& Kirsch, 2018). Additionally, regarding the parents' belief in bi/multilingualism and language acquisition, some parents trusted that being bi/multilingual provides more benefits than monolingualism (Berardi-Wiltshire, 2017). Some immigrant families agreed that learning the second language at an early age is easier for children and language environment will support rapid language acquisition (Moin et al., 2013; Soler \& Zabrodskaja, 2017).

The previous related studies above played a significant role in the design of this study. This study differs from the studies mentioned above. Most of those studies beyond the scope of the EFL context. They focused on immigrant, migrant, transnational families, and multilingual families in multilingual countries. However, there has been no study exploring FLP of the bi-/multilingual families in Palembang, Indonesia particularly focussing on English. Furthermore, various methodologies applied in those studies, such as long term ethnography (Bell, 2013; BezciogluGoktolga \& Yagmur, 2018; Curdt-Christiansen \& Wang, 2018), narrative study (Berardi-Wiltshire, 2017), phenomenological study (Soler \& Zabrodskaja, 2017), mixed-method (Moin et al., 2013), and case study which involved questionnaire in gathering the data (Yazan \& Ali, 2018). Conversely, this study applied a case study design which involved ethnographic interviews with bi-/multilingual families in Palembang. Particularly, this article attempts to answer the following research question, "What were the ideological factors held by two families in Palembang to raise their children bi-/multilingually?" 
Rani Septi Sapriati, et al

\section{LITERATURE REVIEW}

\subsection{Bi-/Multilingualism and Language Policy}

The theory of bi-/multilingualism portrays a human's power to speak talk and understand in two or more different languages. Bilingualism should not be misunderstood with two monolinguals, in which an individual masters two languages equally well (Baker, 1995, 2000; Bassetti, 2013; Bhatia, 2013; Bhatiaa \& Ritchie, 2013; Bialystok, 2013; Kroll \& Dussias, 2013; Steiner \& Hayes, 2009). Since languages are used in a multitude of situations, most people are only skilled in one. Multilingualism, on the other hand, refers to people who are able in two or more languages with different levels of proficiency (Bhatia, 2013; Kaplan \& Baldauf, 1997; Wei, 2013).

Being bilingual or multilingual may give someone positive benefits. Many researchers believe that becoming bilingual and also multilingual facilitates us not only to acquire insight from other cultural backgrounds, but also to participate more enthusiastically in all of these global projects, to boost self-esteem, to promote innovation and academic attainment, to facilitate intergenerational relationships, and to facilitate people to participate with more users around the globe. Similarly, career prospects are being established; it is likely that in the twenty-first century, people will continue to focus emphasis on language skills (Baker, 1995, 2000; K. A. King \& Mackey, 2007; Steiner \& Hayes, 2009)

Within that regard, it is impossible problems-free in bringing up bilingual/multilingual children. Baker (2000), Steiner and Hayes (2009) assert that even before growing bi/multilingual children, parents must make a very well decision. Bi/multilingualism will be helpful in terms of readying how, where, and when a kid will be exposed to languages to ensure that they succeed well. In essence, family plays such an important role in making language decisions for members of the family, particularly their kids. They should actively participate in their children's language development (Curdt-Christiansen, 2009; King et al., 2008; Spolsky, 2009, 2012). It is known as "explicit and overt planning concerning language use within the home among family members" (King et. al, 2008, p. 1). Therefore, it has indeed been treated like as fascinating environment because it is considered a source for the improvement of children's languages.

Spolsky's (2004) language policy framework can be applied to family life to analyze family language policy through the integration of the three main parts suggested by him. Language beliefs (parents' attitudes or core values about language(s), language practices (the real or visible language behavior of family members at home), and language management (parents' efforts to improve existing language practices) are the three aspects (Spolsky, 2004). Among those aspects, the most fundamental aspect is language ideologies as it is the base for shaping other components of language policy. Based on the above-mentioned bi-/multilingual and language 
policy concepts, it is possible to conclude that everybody has the chance to be bi/multilingual.

\subsection{Language Ideologies and $\mathrm{Bi}$-/Multilingual Families}

Language ideologies play a fundamental component in language policy formation. It is about what the person wants to assume about language (Spolsky, 2004). Moreover, he emphasizes that it has "a great value to a national, local or heritage language" (Spolsky, 2004, p. 4). Others also contend that it deals with fundamental factors in language control and usage (Curdt-Christiansen, 2009; King et. al, 2008). Several factors contribute to the formation of parents' language(s) beliefs. It is categorized into two parts: micro-factors and macro-factors (Curdt-Christiansen, 2009; Spolsky, 2004). At the micro-level, it includes sociolinguistic and sociocultural variables such as family literacy, parental desires, parental learning and language experience, and parental comprehension of bi-/multilingualism. However, at the macro level, language ideology demonstrates the economic and socio-political concerns of policymakers, including socio-cultural, political, economic, and sociolinguistic environmental influences. Therefore, this framework gives a response to the essential question of why some children behave bilingual/multilingually and why they experience and practice a second or third language than anything else.

Regarding the macro level, firstly, cultural values play a major role in how parents choose the languages to use in their families; it refers to the symbolic meanings of specific languages. Languages are viewed as a cultural representation from this current perspective since language and culture are intertwined. Languages, as cultural instruments, recognize the identity, faith, and origins. Parents of immigrant and migrant communities, for example, place a high value on their heritage languages. They are based on an appreciation of it as a key component of their community, faith, and identity, as well as a study on the acquisition of an acceptable outlook for a specific culture (Bell, 2013; Berardi-Wiltshire, 2017; BezciogluGoktolga \& Yagmur, 2018; Gogonas \& Kirsch, 2018; Yazan \& Ali, 2018). Hence, cultural factors play a part in shaping the language policy, particularly in the desire to show who they really are. The intertwining sociocultural factors are particularly crucial in shaping the transnational families' language navigations and literacy practices, such as the case of Indonesian education migrant families in the USA (Silvhiany, 2019) and transnational families in the UK (Hua \& Wei, 2016).

Furthermore, language policy is often influenced by the social values that parents hold, and there are several views of specific languages that parents hold in their social capitals. It is concerned with access to the social opportunities provided by a given language and is closely related to economic values (Curdt-Christiansen, 2009; Spolsky, 2004). Some refugee, migrant, or transnational families claim that their bi/multilingual children can reap social benefits such as being able to compete with people in the global economy, encouraging self-esteem, and surviving in society 
Rani Septi Sapriati, et al

(Bell, 2013; Gogonas \& Kirsch, 2018; Moin et al., 2013; Yazan \& Ali, 2018). Language, in other words, aids social purposes.

In terms of economic principles, they belong to the economic pressures elicited by a particular language. In other words, language and economy communicate with one another. These standards concern the extent to which language characteristics influence salaries and earnings. Many parents of bilingual/multilingual families have economic benefits that can help their children pursue a high-paying job or even a promising career in the future, and survive easily in a modern globalized world (Bell, 2013; Berardi-Wiltshire, 2017; Curdt-Christiansen \& Wang, 2018; Gogonas \& Kirsch, 2018; Yazan \& Ali, 2018). To sum up, parental language policy on bi/multilingualism is motivated by parents' wishes to empower their children's financial affairs to achieve a better life.

Political factors play a major role in influencing FLP, as shown by the experiences of multilingual, refugee, and migrant communities. They include individuals' rights and access to education, public events, and government policy (Curdt-Christiansen, 2009), such as language policy and language choice as a right (Curdt-Christiansen \& Wang, 2018; Gogonas \& Kirsch, 2018; Moin et al., 2013). Certain languages are highly valued because they provide a political incentive for bi/multilingual families, especially those wishing to enroll in a specific educational system.

In relation to the micro factor, language acquisition concepts and parental understanding of bi/multilingualism also influence parental language ideologies in a successful FLP. Most parents claim that growing bilingual or multilingual children is preferable to raising monolingual children, that acquiring languages at a young age is simpler for children, and that a proper language atmosphere simultaneously enhance language acquisition (Berardi-Wiltshire, 2017; Moin et al., 2013; Soler \& Zabrodskaja, 2017). Hence, as policymakers, being knowledgeable parents on language acquisition and bilingualism is really necessary to create successful FLP.

\section{RESEARCH METHODOLOGY}

This article is part of a larger study that focused on the complete components of FLP put forward by Spolsky (2004) covering language ideologies, language practices, and language management. However, this article only focuses on one of the objectives of this study that is investigating parental ideologies in raising bi/multilingual children. This qualitative study employed a case study design. This design is applied to understand the particular case both openly and naturally (Creswell \& Creswell, 2018; Creswell, 2013; Tracy, 2013). This design was chosen because it dealt with the phenomenon of the particular group, two families bringing up children bi/multilingually, and one of their languages was English.

This study was conducted in Palembang involving two bilingual families as participants. The first was the Zahra (pseudonym) family. This family is originally from Palembang. Zahra is a lecturer of English at a university in Palembang. Zahra 
just finished her Master's Degree in the English education magister program two years ago. They live in a house that consisting of a mother, two children: a sixmonth-old baby and an adolescent, a grandmother, and two uncles. They raise a twelve-year-old son in more than one language. His name is Fathur (pseudonym). Fathur can speak English fluently, Indonesian, and understands Palembang language, as well. He is now in the 7th grade of an Islamic junior high school in Palembang.

The second one was the Najwa (pseudonym) family. This family consists of a Javanese father, a mother from Tulung Selapan (a region in South Sumatera), and a daughter. Najwa has a bi-/multilingual 9-year-old daughter. Her daughter now studies at a bilingual school in Palembang. Her name is Alia (pseudonym). She is in the 3rd grade. She can speak English and Indonesian. Furthermore, she understands a little bit Palembang, Javanese, and also Mandarin languages. She speaks English at school. She sometimes speaks Indonesian with her mother but mostly English.

There were three kinds of data sources in the larger study, viz: etnhographic interviews, participant observations, and artifacts. However, ethnographic unstructured interviews were only used in exploring the data deeply about their ideological factors to shape FLP. An ethnographic interview is a casual interview that is evolving, random, and typically happens in the field study (Spradley, 1979; Tracy, 2013). These interviews were conducted more than twice in a casual context for 1.5 to 2.5 hours during participant observation times with the consideration that it was better to perform two or shorter interviews during participant observations or weekly home visits than setting a different meeting for one longer interview. A good relationship between the researcher and the participants had been built because of the researcher's positionality as their neighbor and relative. Thus, these conditions made them felt more comfortable in sharing their FLP without being nervous and made us easier to get much information. The interviews were recorded using tape and video recordings. In the Zahra family, the mother, son, and grandmother were interviewed as the father did not stay in that house. However, in the Najwa family, mother, father, and daughter were interviewed. Most of the interviews portrayed a dialogue between neighbors and relatives rather than a researcher-interviewee condition. Each interview was carried out in different languages; Palembang language, Indonesian and English, depending on the interviewee's convenience. In the Zahra family, Palembang language was used with mother and grandmother, while English was used with children. However, in the Najwa family, the mother was convenient to use English in conversations as it is her language policy to use it at home and with father the interview was conducted in Indonesian language.

The data of this study were analyzed using the standard procedure for analyzing qualitative data as suggested by Creswell, (2013, 2014), Creswell \& Creswell (2018), Saldana (2016). Thematic analysis involved in this procedure. Firstly, the interview recording files were prepared and listened to many times. Second, all the 
Rani Septi Sapriati, et al

recording files were transcribed in verbatim and were read line-by-line several times to obtain a clear understanding. Tools such as Microsoft word and excel were used to facilitate the coding process. Open coding was applied in the first stage of the coding process where the significant sentences or paragraphs from verbatim transcriptions were segmented to tentative initial codes. Those initial codes were compared to each other and classified into some categories (axial coding). Lastly, in the selective coding, the categories were grouped into major themes which were related to the ideological factors held by these two families in Palembang in shaping FLP. For example, the theme "Social Factors" was formed from the category "Surviving in the world" and "Surviving in the society", and the category of "Surviving in the world" was obtained from the open coding "communicate with people from other countries" and "communicate with people from outside Palembang". These open codings were obtained from the participants' statements as follows:

"I support Alia fully in learning English because she has a dream to go to Mecca, England...so, I encourage her to use it in her daily communication to improve her English" (Alia's father)

“...If he only knows Palembang language, he doesn't master Indonesian or English, he will get lost if he goes to other cities..." (Fathur's grandmother)

Then, the major themes were analyzed and expressed qualitatively with a broad discussion to present the research results; a thick description was included in this process to verify the trustworthiness of the data. The final stage was to discuss the findings by questioning lessons that can be learned, comparing and contrasting the results with the concepts or theoretical framework and literature reviews. The whole results were discussed with the participants (member checking).

\section{FINDINGS}

The findings of this study revealed that the two families have straightforward and transparent values and attitudes concerning bi-/multilingualism in the case of their kids. Political, social, and cultural awareness may support their kids in terms of survival in society, personal identity, and economic participation, as well as providing visible prospects and varied paths in life. The parents' background and experiences affected their views of language and literacy learning, as well as the educational benefits. These families put their ideas into practice by constructing a FLP and ensured educational assistance they believed may facilitate their children's success.

\subsection{General Characteristics of Bi-/Multilingual Families}

Based on the collected data, we got much information regarding the FLP of the Zahra and the Najwa families. As seen in Table 1 about the language background of 
each participant, it can be assumed that Fathur and Alia were living in a multilingual and multicultural context where multiple languages are practiced around them.

In Zahra family, an adolescent son, Fathur, is fluent in English. He practices it alone and with his mom because his mom is also competent of English. He speaks English fast without thinking about the grammar mistakes, the word choices and the way to pronounce it as he is already good at all of these. He is more fluent in English than Indonesian. Although he lives in a city where the local language, Palembang language, is dominantly used by people around him, he still uses standard Indonesian to communicate with other family members, neighbors, and at school. However, it does not mean that he does not understand Palembang language; he just cannot speak it like a native even though it is his parents' native language. Fathur is sent by his mother to an English course to maintain his English and to practice it with the English teacher there. Furthermore, his mother also puts him to a Tahfidz club to get more exposure in Arabic for religious purposes. Not only that, but his mother also wants him to interact with their neighbors to get the local language.

On the other hand, in Najwa family, a nine-year-old daughter, Alia, is also English speaking kid. She is more comfortable using English rather than Indonesian. She interacts with her mother mostly in English most of the time; however, they sometimes mix it with Indonesian and Palembang when she feels appropriate to use them. Moreover, she practices mostly Indonesian with her dad. Sometimes her dad mixes and switches the conversation into Indonesian, English and Javanese. To improve Alia's English skills, her parents put Alia in a bilingual school program in Palembang that practices the use of English and Indonesian in the classroom. She also communicates with relatives from her mother in multilanguage such as English, Indonesian, and Palembang. Therefore, it can be assumed that these two families have different ways of shaping the FLP at home. The following Table 1 explains the language background of the Zahra family and the Najwa family.

Table 1 Participants' Language Background

\begin{tabular}{|c|c|c|c|c|c|c|c|}
\hline \multirow{2}{*}{$\begin{array}{l}\text { Family } \\
\text { Member }\end{array}$} & \multirow{2}{*}{ Education } & \multirow{2}{*}{$\begin{array}{l}\text { City of } \\
\text { Birth }\end{array}$} & \multirow{2}{*}{$\begin{array}{c}\text { First } \\
\text { Language }\end{array}$} & \multicolumn{4}{|c|}{ Language Proficiency } \\
\hline & & & & English & Indonesian & Palembang & Javanese \\
\hline \multicolumn{8}{|c|}{ Family 1} \\
\hline $\begin{array}{l}\text { Grand- } \\
\text { mother }\end{array}$ & $\begin{array}{l}\text { Bachelor } \\
\text { Degree } \\
\text { Master }\end{array}$ & Palembang & Palembang & Beginner $^{\mathrm{a}}$ & Proficiency ${ }^{\mathrm{f}}$ & Proficency & Beginner \\
\hline Mother & $\begin{array}{l}\text { Degree in } \\
\text { English } \\
\text { Education }\end{array}$ & Palembang & Palembang & Proficiency & Proficiency & Proficiency & Beginner \\
\hline Son & $\begin{array}{c}\text { Junior high } \\
\text { school } \\
\text { student }\end{array}$ & $\begin{array}{l}\text { Bekasi, } \\
\text { Jakarta }\end{array}$ & $\begin{array}{c}\text { Bahasa } \\
\text { Indonesia }\end{array}$ & Proficiency & Elementary ${ }^{\mathrm{b}}$ & Beginner & None \\
\hline
\end{tabular}

Indonesian Journal of EFL and Linguistics, 6(1), 2021 
Rani Septi Sapriati, et al

\begin{tabular}{|c|c|c|c|c|c|c|c|}
\hline \multicolumn{8}{|c|}{ Family 2} \\
\hline Father & $\begin{array}{l}\text { Bacelor } \\
\text { Degree }\end{array}$ & Java & Javanese & Beginner & Proficiency & Beginner & Proficiency \\
\hline Mother & $\begin{array}{l}\text { Bachelor } \\
\text { Degree in } \\
\text { Engineering }\end{array}$ & $\begin{array}{l}\text { Tulung } \\
\text { Selapan, } \\
\text { South } \\
\text { Sumatra }\end{array}$ & $\begin{array}{l}\text { Tulung } \\
\text { Selapan }\end{array}$ & Intermediate $^{c}$ & Proficiency & Proficiency & Beginner \\
\hline Daughter & $\begin{array}{l}\text { Elementary } \\
\text { school } \\
\text { student }\end{array}$ & Jakarta & $\begin{array}{c}\text { Bahasa } \\
\text { Indonesia }\end{array}$ & Advanced $^{\mathrm{e}}$ & Proficiency & Beginner & None \\
\hline \multicolumn{8}{|c|}{$\begin{array}{l}\text { Note. This table demonstrates the level of participants' language proficiency of each language. The guideline } \\
\text { used to measure the language proficiency is the Common European Framework of Reference for Languages: } \\
\text { Learning, Teaching and Assessment (CEFR or CEF) Adapted from "Levels of Language Proficiency: Where are } \\
\text { you?" by D.Hagstorm, 2015, Language Articles (https://talkwithmyneighbor.com/levels-of-language- } \\
\text { proficiency/). }\end{array}$} \\
\hline \multicolumn{8}{|c|}{ Beginner: can comprehend and use basic and very simple daily words } \\
\hline \multirow{2}{*}{\multicolumn{8}{|c|}{$\begin{array}{l}{ }^{\mathrm{b}} \text { Elementary: can comprehend statements and commonly used terms relating to issues of significant concern } \\
\text { 'Intermediate: can comprehend the main idea of unambiguous input source on general topics, cope with most } \\
\text { conditions, and generate basic text }\end{array}$}} \\
\hline & & & & & & & \\
\hline \multicolumn{8}{|c|}{$\begin{array}{l}\text { d Upper Intermediate: Can communicate at a level of fluency and spontaneity that allows for regular conversation } \\
\text { with native speakers without effort on either party. }\end{array}$} \\
\hline \multicolumn{8}{|c|}{${ }^{\mathrm{e}}$ Advanced: can articulate thoughts fluently and spontaneously without obvious seeking for words } \\
\hline \multicolumn{8}{|c|}{$\begin{array}{l}{ }^{\mathrm{f}} \text { Proficiency/Mastery: can grasp practically everything heard or read, and express himself/herself freely, very } \\
\text { smoothly, and greatly, separating finer shades of meaning even in the most difficult situations }\end{array}$} \\
\hline
\end{tabular}

\subsection{Ideological Factors that Shaping FLP}

Concerning the aspect of language ideologies, based on the data analysis, five themes were emerged: (1) Political Factor, (2) Social Factor, (3) Cultural Factor, (4) Economic Factor, and (5) Parents' knowledge on Language Acquisition and Bi/Multilingualism. These factors are the most essential in encouraging these two families' actions. In the main body of this article, we clarify how parents view bi/multilingualism and the multiple values associated with languages concerning those factors mentioned before.

\subsubsection{Political Factor}

The Zahra and Najwa families' FLP was heavily associated with political issues. The political values held by these multilingual families were that using English as a right to participate in the use of the wolrd's language and as a language used at school.

\section{Using English as a right to participate in the use of the world's language}

One of the factors influencing the family language policy of Palembang's multilingual families is the new idea that the increasing popularity of English changes their cultural values toward their native languages. In other words, their perception of their language use has shifted due to political issues as English is the international language spoken by billions people either officially or as a second language. Najwa claimed undeniably that their family motive in raising Alia with English, "of course because English is an international language so we can speak 
English everywhere in other countries, in Japan we can speak English, so many people understand about language". Furthermore, this motive was also declared by Fathur, a bilingual son of the Zahra family "....hmmm to be honest I just want to learn it, that's all. Cause it's interesting because it's an International language where every people around the world speak it". Therefore, their beliefs on the use of English enabled them to use their right to participate in the use of the global language. It can be seen from their responses that they had the enthusiasm to use it as it is an international language.

English as a language used at school

Although in Indonesia, the status of English is as the first foreign language, it is not rare to find schools that apply English as a medium of instruction at school. This fact was one of the reasons for constructing Najwa's FLP. As her husband answered the crucial of English for Alia, " Dan sekolah Alia juga dual bahasa... bahasa Asing juga, bahasa Indonesia juga. Ya gak ma?" (Translation: Her school is a duallanguage...either foreign language as well as Indonesian. Right, ma?) said Alia's father. Therefore, reflecting from the Najwa family experience in English, their language ideologies were also shaped because they want to be able to participate in an educational system as they put Alia to a school that applied dual language in the learning process. Thus, certain language gains high value to be used as it includes a political reason for bi/multilingual families, especially to take part in using international language, facing globalization era and continuing education.

\subsubsection{Cultural Factor}

Cultural beliefs contribute to how parents choose the languages to use in their households. Languages are perceived as a cultural representation from this viewpoint, as culture and language are closely tied. As a cultural device, language portrays identity, faith, and ethnicity. However, in this context, both parents of the two families hold cultural values strongly just to sustain their national and religious identity. They did not have a strong desire to maintain their ethnicity.

\section{Indonesian is important to maintain national identity}

The parents of two multilingual families respected their national language so much. In the Zahra family case, she wanted his son to master Indonesian as he was not fluent in using Indonesian both orally and written. Fathur was better at English than Indonesian and Palembang. It can be seen clearly in the mother's response in the excerpt below when I asked her about her plannings in raising a multilingual child, "Idak katek rencana nian. Dio dulu pacak ngomong be Alhamdulillah. Pacak ngomong bahasa Indonesia"'(Translation: I don't have any plans. I used to hope if he could speak I would be very grateful. In Indonesian of course!) said Zahra. Based on this remark, it was clear that Zahra had hoped that her son could speak Indonesian fluently as her son was dominantly speaking English. Similarly to the Najwa family, the mother is concerned about the first language of her children. She mentioned that 
Rani Septi Sapriati, et al

Indonesian is the most important language to be mastered by Alia as they are part of that nation, “...Alia's mother language is very good. Because we're Indonesian right?, and now we live in Indonesia so it is important for her".

Growing up and living in Indonesia which part of multilingual countries required them to speak Indonesian as the unifying language of the nation. These beliefs were also supported by the children. It was stated clearly when they were asked about what language that they used to speak with people around them such as their relatives, "because we live in Indonesia... so we speak Indonesia..." said Fathur. Then, Alia also showed her love for Indonesia, "cause I love Indonesian, cause it's my country". Hence, the use of Indonesian by these two bi-/multilingual children was their contribution as Indonesian citizens and an act to show their nationalism.

\section{Conflicting to maintain ethnic identity}

Living in a multilingual country, Indonesia, which has got a lot of ethnic languages and only one national language, both mothers and children had a negative attitude toward the use of their heritage language for children. They preferred to maintain their national identity to their ethnicity. However, it was different from Najwa's husband who said that national, regional, and global languages are important for their daughter as an identity marker.

Najwa stated clearly that she was not comfortable if her daughter speaks Palembangese as it is rude to be spoken by Alia. "Hmmmm I think it is sedikit kasar (rather rude) when Alia talked in Palembang. I'm not comfortable with it. I think, it will be bad and English is better" confirmed Najwa. Likewise, Zahra also clarified that she and the other family members were rarely in using their native language to Fathur, "Dak pernah ngomong bahaso Palembang samo dio. Dak tau ngapo. Dio dak dibiasoke ngomong bahaso Palembang. Palembang tu dikiiiiiit banget sama dia ini, bahasa Indonesia, bahasa Inggris yang paling besak"(Translation: I never use Palembang language with him. I don't know why. He has not been accustomed Palembang language. The use of Palembang language is very rare with him, Indonesian and English are dominant). It was also noticeable from the children's response when they were questioned about the use of Palembang at home. They stressed that they understood it but they were not accustomed to use the language although their mothers used it with the others. Alia said "My mom doesn't want me to practice Palembang so I can't speak Palembang”. Similarly, Fathur also mentioned, "Hmmm.... I don't know they just speak Indonesian. That's all”. In terms of maintaining their heritage language, both Zahra and Najwa seemed did not have strong motive to make their children able to speak the Palembang language.

In contrast, Alia's father, a Javanese, has a different view from his wife, in raising kid in more than one language. He believed that either heritage language or global language is important to be mastered, "Biar tau oh begini bahasa jawa...jadi bahasa daerah harus tahu, bahasa asing juga harus tahu seperti itu...semua nya harus 
saling melengkapi saling mendukung"(Translation: I want her to know Javanese language...so, she must know regional language as well as global language. They should support each other).

Therefore, according to the finding of this study, mothers had a strong decision on the use of their own heritage language. It was because the mother-child interaction is more frequent than father. Although the father valued the languages at the same level, the mother is still as decision maker. However, regarding this conflict, it was also undeniable that the heritage language was still introduced to children. Thus, it is worth noticing that mastering English does not come at the expense of losing her identity as an Indonesian, specifically as a Javanese and Palembangese.

\section{Maintaining religious identity}

Zahra and Najwa also recognized that acknowledging Arabic is also important for their children as it is the language for religious purposes. As an instance, Najwa said,

Exactly, if I can speak Arabic, maybe I will teach Alia Arab because it is more improtant. That's why I say to her "Alia, you must study Arab! You must know how to speak Arab because your mom cannot".

Not only that, Zahra also stressed, “.....Malah lebih fokusnyo ngaji, sholat cakitu” (Translation: .....I even focus him on reciting Qur'an and take prayer). Based on the excerpts-mentioned, it was presumed that to preserve their Muslim identity, Najwa and Zahra realized the importance of Arabic in supporting their children in any form of religious practice. Instead of using it for daily communication, they are concerned about it such as how to recite the Qur'an, taking prayer, and other Islamic actions. It was revealed that Zahra enrolled his son in the Tahfidz club and guided him to read the Qur'an with his grandmother every evening. Their beliefs showed that their kids' failure to understand or speak Arabic hide their identity as Muslims.

To summarize, language has been seen as representations of identity, such as state, ethnicity, religion, and origin. Palembang language was still practiced at home by other family members even though both mothers were uncomfortable if their children spoke the local language. As a result, their ethnic language will not be lost. Their identity as Palembangese, Javanese, and Indonesian is still maintained. They also sustain their identity as Muslims as they supported their kid to learn Arabic even though for religious purposes. Consequently, they have colored who they are by understanding and using those languages.

\subsubsection{Social Factor}

The next belief held by the participants in this study was social values. The participants were consistent in their view that raising children multilingually will provide them with social benefits such as longevity in their society and in the world. These values inspired the Najwa and Zahra families' use of Indonesian and English 
Rani Septi Sapriati, et al

to construct their FLP as they were more concerned with those languages rather than their heritage language, Palembangese, and Javanese.

\section{Surviving in the world}

The participants claimed that the role of English is directly linked to society and the global language. It is important to master English in today's era since it is known as the world language. Thus, those who do not master English will be left behind. Fathur's grandmother illustrated her attitude toward the use of Indonesian and English which are closely related to the social value, "men pacak bahasa Inggris tu dimano be diterimo. Men nak keluar negeri kemano mano" (Translation: Those who master English will be accepted everywhere, such as, going abroad or somewhere). This statement highlighted the effect of global language in assisting children living in the world. They will not face difficulty wherever they live and go as long as they can interact and participate in social activities with their community. Therefore, it is crucial to be multilingual instead of being monolingual in their heritage language only.

\section{Surviving in the society}

One of the mothers of these two families was influenced by the social needs. Zahra thought that if Fathur is not able to use Indonesian, he will not be able to socialize with society. Therefore, in this social context, Zahra did great efforts to make his son fluent in Indonesian and in their local language by taking him to a non-bilingual school program to improve his Indonesian and get more exposure to Palembang language from the local speakers. She was also worried that her son would be mocked by others as he speaks it strangely. She said, “....He even speaks differently from normal people until now. I am really afraid that he will be bullied by others. For example, he says "ayolah jangan begitu, masak, kamu mau saya begitu?"'(Translation: come on, don't be like that, why do you want me like that?). It is apparent that language has a strong connection to social life. These mothers believed that their multilingual kids will be accepted in every place they stay. As a result, mastering both Indonesian and English provide good opportunities for their kids to get involved in the world society. In other words, languages encourage humans' social advancement.

\subsubsection{Economical Factor}

\section{Mastering English is an investment for future}

According to the family language policies of these multilingual families, they held motive to grow their economic life. The market conditions caused by a given language decide economic values or vice versa. The Najwa and Zahra families claimed that bi/multilingualism generates economic features that help children have a better life so they already prepared for their children's future life. For example, Najwa stated as follows: 
I think that's pure lah why I chose Alia to speak English everyday, everywhere and everytime at school, at home. I hope.... I HOPE.....I don't make Alia to be hard in the future heheheh, when she can speak English.

Furthermore, Fathur's grandmother said that although Fathur's English was already good he still needs a certificate from the English course as an evidence that he has good proficiency in English, as it is commonly known that the English certificate is very useful for applying for a better job. Thus, it was recognized that parents believed that their children's future life will be much better with English as it is interrelated each other between economic value and language.

An attitude in facing the flow of globalization

By speaking English, the kids will have ease in the future, especially in competing newly globalized where free trading is happening in this era. Najwa's husband strongly believed that Alia will be successful in this era, “...bahasa inggris...dijaman seperti ini sangat penting sekali karena untuk menghadapi era globalisasi jadi semua pasar dari seluruh dunia akan membanjiri Indonesia" (Translation: ....English....in this era, it is very important to face the globalization era so all markets from all over the world may come to Indonesia).

In brief, it can be inferred that parental language policies on bi-multilingualism played a role in empowering family members' economic perspective by providing a chance for their children to prepare better future life and be competitive in today's economic competition.

\subsubsection{Parents' Knowledge of Language Acquisition and Bi-/Multilingualism}

Parents' skills and language experience

Another ideological factor that influenced the formation of the Zahra's and the Najwa's FLP was their knowledge of language acquisition and bi-/multlingualism concept. These two families held this belief because it was based on their background and their experience in learning English. Both Fathur and Alia practice English mostly with their mother only, it is because Fathur's mother has good proficiency in English and she is a professional teacher of English, "because my mom is an English teacher" said Fathur. Also, Alia's mother has experience in English before she raised her daughter with English, "Yaa, saya dulu kursus" (Translation: Yes, I used to join English course) stated Najwa.

Based on this language background, it can be inferred that they were aware about language acquisition and bi-/multilingualism as variables affecting their language policy at home. In this case, they held two views about their language policy. For instance, they believed that children's verbal intelligence played a significant role in their ability to communicate in English.

Indonesian Journal of EFL and Linguistics, 6(1), 2021 
Rani Septi Sapriati, et al

\section{The role of linguistic intelligence}

It was fully clarified by Zahra that she completely believes that his son's English skills already exist since he was born. This belief was expressed as Fathur is more proficient in English than in Indonesian since he was kid until now. He also used to experience speech delay when most of his friends were already able to talk. Hence, his mother trusted that Fathur got confused because people around him talked in Indonesian and Palembang. "kali otaknyo tu lebih terekam bahasa Inggris" (Translation: May be his brain accepts English more) added Fathur's grandmother. Zahra also shared her experience when she were taking care of the baby Fathur:

....Nah pas mbak nuangke susu make bahaso Inggris "one, two, three" nah dio tu pecak ngerti cakitu nah, cak klick pas kito ngomong. Cak kenal samo suaro itu. Nah dari situlah mbak tu sadar, mungkin memang apoyehh, dasar bahasa Inggrisnyo tu ado (Translation: When he was still a baby, he was sensitive to what I was talking about. In a situation when I was pouring milk and I said in English such as, "one, two, three" and he seemed to understand and responded it directly. From this, I realized that he seemed to have English skills since birth).

Based on their experience in raising Fathur, it can be seen that it was possible for Zahra and her mother to strongly believe that Fathur has English skills since his birth. Therefore, also it becomes the basis for them to make decisions about their family language policy at home although it is not written formally they already know that he already holds this ability.

\section{The importance of partner in practicing language}

Najwa and Zahra believed that one of the reasons that their children had good English proficiency was from the mother themselves because they practiced it constantly at home. “.... Pas pulok mbak pacak bahasa Inggris. Bahasa Inggris tu kan asak ado yang ngerewangi ngomong. Samolah cak bahaso jawo. Sudah asak diasah ini, terexpose dio" (Translation: ....By coincidence I can speak English. English is improved if we have partner to practice it. It is like other languages, such as Javanese. The more we practiced, the more it is exposed. Therefore, we just continue English conversation in our daily life) mentioned Zahra.

It was also heard when she advised Fathur about the tips to master a language. She emphasized that the role of a partner in practicing the language is good to get the improvement in the language, as shown in the interview excerpts below.

If you want to learn a language, you need someone to talk to... you need someone who understands... you need people to interact in community...to be able master a language... if you learn by yourself it's going to be hard. I do not say it's impossible but it's going to be hard.. if you have someone to talk with in Japanese... you will learn it faster! 
This fact was also supported by the Najwa family; she also believed that the success of Alia in understanding and using more than one language was because she had a mate to practice it. Incidentally, she could speak English; therefore, she practiced it with her daughter. However, she also considered that practicing it with mother only was not enough so she sent Alia to a bilingual school to get more exposure to English.

These facts indicate that these two families raised their children using more than one language. They lived in a multilingual context consisting of multilingual culture although in raising their multilingual children they gave their children different levels of language exposure. In these two families, the mothers played a big role in shaping language policy at their family as well as giving much exposure to the language by encouraging children to practice English with themselves.

\section{DISCUSSION}

This case study illustrates the ideological factors toward the languages used in particular that shape the language policy of two bi-/multilingual families in Palembang. The results of the analysis of ethnographic interviews with the family members showed how their perceptions toward heritage, national, and global language form their beliefs on bi-/multilingual, what values affected their decisions of language use at home and what concepts they believe to assist the language development for children. There were some factors found underlying the shaping of the participants' FLP, such as political, social, economic, cultural factors, as well as the parents' knowledge on language acquisition and bi-/multilingualism. This finding was in a line with Spolsky's (2004) concepts about factors affecting language ideology which he divides into macro and micro levels.

Both families raised their children with more than one language that are Indonesian, English, Palembangese, and Javanese, as well as Arabic for religious purposes. Each language was mastered at different proficiency level. English was used as the major language as children found it enjoyable to communicate with mother. The second main language was Indonesian and the last options were their heritage language Palembangese and/or Javanese. It can be confirmed that they are multilingual children as they could use more than one language regardless of different level of language proficiency (Baker, 1995, 2000; Bassetti, 2013; Bhatiaa \& Ritchie, 2013; Bialystok, 2013; Kaplan \& Baldauf, 1997; Kroll \& Dussias, 2013; Steiner \& Hayes, 2009; Wei, 2013). Both families also clarified that they did not force their children to master all languages. However, they provided more exposure to English than other languages. Therefore, their kid was much better at English than other languages used in the family.

Living in Indonesia which has a lot of languages did not stop these parents to provide their children exposure to English. This behavior was affected by political factors. Because of the status of English as an international language and as a 
language used at school, the parents considered learning English as an important investment for the future. Curdt-Christiansen (2009) mentioned that the rights and access of persons to education, civic activities, and government decisions in certain languages were shaped by political values. Accordingly, it was evident in some contexts of bi-/multilingualism in the world such as multilingual families in China (Curdt-Christiansen \& Wang, 2018), migrant Greek families' experiences in Luxembourg and Turkish families living in the Netherlands (Gogonas \& Kirsch, 2018). Russian immigrant parents in Israel (Moin et al., 2013) had modified their language use because of the growth of English in education. Thus, they wanted to be able to use international language and fulfill the prerequisite to join a certain school.

Not only to take their right to use the international language but they also had a strong desire to hold their national identity. Instead of preserving their mother tongue, they prefer to use the national language to show their identity as part of Indonesia. Both mothers of these two families viewed heritage language as not necessary to be preserved. As a result, one of the fathers in these families had a conflict with his wife to maintain their heritage language. In contrast, some immigrant and migrant families who lived in other countries whose language is different from their language affected their decision to use heritage language at home to maintain their culture and identity (Berardi-Wiltshire, 2017; BezciogluGoktolga \& Yagmur, 2018; Gogonas \& Kirsch, 2018; Yazan \& Ali, 2018), they did not want to be affected by other's culture even though they lived overseas (Bell, 2013; Berardi-Wiltshire, 2017; Bezcioglu-Goktolga \& Yagmur, 2018; Yazan \& Ali, 2018) and they also emphasized that children's failure to speak the heritage language causes a rift in family relationships (Bell, 2013; Moin et al., 2013). The mothers' ideologies to form their FLP were shifted because of the growth of English. It was declined by Curdt-Christiansen (2009)on multilingualism. She stressed that the use of international language must not be the cause the loss of heritage language. Furthermore, maintaining Arabic was also inspired them to encourage their kid to learn their religion. This finding is in a line with the studies on immigrant families in the US that highlight the importance of Quranic Arabic to facilitate religious rituals and the learning of Qur'an, Sunnah, and other sources of Islamic principles (Silvhiany, 2019; Yazan \& Ali, 2018). As a consequence, the motives of parents in raising bi-/mutlilingual children are slightly different from immigrant or migrant contexts which prioritize their heritage language to be used at home rather than global or local language to keep up their clothes.

Furthermore, based on the deep exploration toward the bi-/multilingualism on these families, it was found that their FLP was also influenced by the social factor, which is related to survival. The ability to use or understand more than one language assists them to be involved in the global society. Although their children did not have the balance ability in each language they speak, they believed that their children will still exist wherever they live. It was approved by immigrants and migrants in the US, UK, and New Zealand that English is needed to help them live in the environment 
(Bell, 2013; Bezcioglu-Goktolga \& Yagmur, 2018; Yazan \& Ali, 2018). Furthermore, Moin et al. (2013)revealed that regardless of where people live, they must be able to communicate in their local dialect to connect with members of the community. Thus, multilanguage creates a way for humans to promote social life.

The next ideological factor which greatly shaped the language policy of these two families was economic values. In line with Spolsky (2004) and Curdt-Christiansen (2009) that the use of certain language is strongly linked to economic values. These families viewed bi-/multilingualism as an economic benefit for their kids especially when they grow up. Likewise, some parents of multilingual children in China, Spanish-English speaking children in New Zealand, and some multilingual Chinese families in Scotland claim that bi/multilingualism offers economic advantages that can help children get high-paying employment or a successful future career (Bell, 2013; Berardi-Wiltshire, 2017; Curdt-Christiansen \& Wang, 2018). Furthermore, they also believed that by raising bi-/multilingual children, their children will have an ease in facing the globalization era such as free trading which global language is needed for this Gogonas and Kirsch (2018) found some multilingual kids' parents with French, English, and German create language ideologies with the intention that their kids can easily compete in modern globalized, transnational, and post-industrial worlds. In brief, raising multilingual kids, particularly with English, is trusted to give the economical enhancement for their future.

Finally, the language policy of these two multilingual families was also shaped by the parents themselves, either through their knowledge or experience. Regarding their knowledge, parents considered that one of the factors affecting kids to speak more than one language, particularly to master a foreign language, English, fast is from the kids themselves. It implies that the children's linguistic intelligence has a huge effect on their choices about language usage at home. Erlina et al. (2019) discovered that each individual has a different degree of linguistic intelligence, the competence to use language orally or written. Also, Armstrong (2009) claimed explicitly that it is prompted by three factors: genetic endowment, personal background, and cultural and historical background. As a consequence, these families also perceived that way. They thought that their presence is in a significant position for the success of their bi-/multilingual children as they guide them in practicing those languages. Even so, children learn languages more quickly when they are young, and a good language environment leads to successful language acquisition (Berardi-Wiltshire, 2017; Moin et al., 2013; Soler \& Zabrodskaja, 2017). They contended that families, particularly parents, contribute to offering a language environment at home for bi/multilingual children. After all, a good parenting concept is essential for parents who are having children who speak more than one language. 
Rani Septi Sapriati, et al

\section{CONCLUSION}

This article discussed the ideological factors that influenced the language policy of two bi/multilingual families in Palembang, especially those who raised their children in English. The findings indicate that in this setting, families, particularly mothers and children, were highly aware of the use of English in their daily conversation. Social, political, and economic needs had a significant effect on their FLPs. This study also demonstrates that parents' knowledge of language acquisition and bi/multilingualism also played a large part in developing their FLPs. However, in relation to the cultural factors, these two families emphasized more on the use of national language rather than their heritage language. The reality that these families did not place a focus on their children's growth in their heritage language revealed that they valued international and national languages more than the local one. Further studies on the larger-scale investigating on family language policies are hoped to share more than this current study. Researchers are encouraged to not only address the factors that shape linguistic ideologies but also the challenges families face and the involvement of each family member in constructing the FLPs.

\section{REFERENCES}

Armstrong, T. (2009). Multiple intelligences in the classroom (3rd ed.). ASCD.

Baker, C. (1995). A parents' and teachers' guide to bilingualism. Multilingual Maters.

Baker, C. (2000). A parents' and teachers' guide to bilingualism: Parents' and teachers' guide 1 (2nd ed.). Multilingual Maters.

Bassetti, B. (2013). Bilingualism and writing system. In T. K. Bathia \& W. C. Ritchie (Eds.), The handbook of bilingualism and multilingualism (pp. 649670). Willey-Blackweel.

Bell, E. (2013). Heritage or cultural capital: ideologies of language in Scottish Chinese family life. Asian Anthropology, 12(1), 37-52. https://doi.org/10.1080/1683478x. 2013.773602

Berardi-Wiltshire, A. (2017). Parental ideologies and family language policies among Spanish-speaking migrants to New Zealand. Journal of Iberian and Latin American Research, 23(3), 271-285. https://doi.org/10.1080/13260219.2017. 1430489

Bezcioglu-Goktolga, I., \& Yagmur, K. (2018). Home language policy of secondgeneration Turkish families in the Netherlands. Journal of Multilingual and Multicultural Development, 39(1), 44-59. https://doi.org/10.1080/01434632.2017. 1310216

Bhatia, T. K. (2013). Introduction. In T. K. Bathia \& W. C. Ritchie (Eds.), The handbook of bilingualism and multilingualism (pp. 3-5). Willey-Blackweel.

Bhatiaa, T. K., \& Ritchie, W. C. (2013). Bilingualism and multilingualism in South Asia. In T. K. Bathia \& W. C. Ritchie (Eds.), The handbook of bilingualism 
and multilingualism (pp. 843-870). Willey-Blackweel.

Bialystok, E. (2013). The impact of bilingualism on language and literacy development. In T. K. Bathia \& W. C. Ritchie (Ed.), The handbook of bilingualism and multilingualism (pp. 624-648). Willey-Blackweel.

Caldas, S. J. (2012). Language policy in the family. In B. Spolsky (Ed.), The cambridge handbook of language policy (pp. 351-373). Cambridge University Press.

Creswell, J. W. (2013). Qualitative inquiry \& research design: Choosing among five approaches. In SAGE (3rd ed.). SAGE.

Creswell, J. W. (2014). Research design qualitative, quantitative and mixed method approaches (4th ed.). SAGE.

Creswell, J. W., \& Creswell, D. W. (2018). Research design qualitative, quantitative and mixed method approaches (5th ed.). SAGE.

Curdt-Christiansen, X. L. (2009). Invisible and visible language planning: Ideological factors in the family language policy of Chinese immigrant families in Quebec. Language Policy, 8(4), 351-375. https://doi.org/10.1007/s10993009-9146-7

Curdt-Christiansen, X. L., \& Wang, W. (2018). Parents as agents of multilingual education: family language planning in China. Language, Culture and Curriculum, 31(3), 235-254. https://doi.org/10.1080/07908318.2018.1504394

Erlina, D., Marzulina, L., Astrid, A., Desvitasari, D., Sapriati, R. S., Amrina, R. D., Mukminin, A., \& Habibi, A. (2019). Linguistic intelligence of undergraduate EFL learners in higher education: A case study. Universal Journal of Educational Research, 7(10), 2143-2155. https://doi.org/10.13189/ujer.2019.071012

Gogonas, N., \& Kirsch, C. (2018). 'In this country my children are learning two of the most important languages in Europe': ideologies of language as a commodity among Greek migrant families in Luxembourg. International Journal of Bilingual Education and Bilingualism, 21(4), 426-438. https://doi.org/10.1080/13670050. 2016.1181602

Hagstorm, D. (2015). Levels of Language Proficiency: Where are you? Language Article. https://talkwithmyneighbor.com/levels-of-language-proficiency/

Hua, Z., \& Wei, L. (2016). Transnational experience, aspiration and family language policy. Journal of Multilingual and Multicultural Development, 37(7), 655666. https://doi.org/10.1080/01434632.2015.1127928

Kaplan, R. B., \& Baldauf, R. B. (1997). Language planning: From practice to theory. Victoria.

King, K. A., \& Mackey, A. (2007). The bilingual edge. HarperCollins.

King, Kendall A, Fogle, L., \& Logan-Terry, M. (2008). Family language policy \& planning. Language and Linguistics Compass, 5(2).

Kroll, J. F., \& Dussias, P. E. (2013). The comprehension of words and sentences in two languages. In T. K. Bathia \& W. C. Ritchie (Eds.), The handbook of 
Rani Septi Sapriati, et al

bilingualism and multilingualism (pp. 216-243). Willey-Blackweel.

Moin, V., Scwartz, L., \& Leikin, M. (2013). Immigrant Parents' Lay Theories of Children's Preschool Bilingual Development and Family Language Ideologies. International Multilingual Research Journal, 7(2), 99-118. https://doi.org/ 10.1080/19313152.2011.651397

Romaine, S. (2013). The bilingual and multilingual community. In T. K. Bathia \& W. C. Ritchie (Ed.), The handbook of bilingualism and multilingualism. Willey-Blackweel.

Saldana, J. (2016). The coding manual for qualitative researchers (3rd ed.). SAGE.

Silvhiany, S. (2019). Indonesian education migrant families' language, literacy, and identity navigations in transnational spaces (Publication No. 13900644) [Indiana University]. ProQuest Dissertations and Theses Global

Simpson, A. (2007). Language and national identity. Oxford University Press.

Soler, J., \& Zabrodskaja, A. (2017). New spaces of new speaker profiles: Exploring language ideologies in transnational multilingual families. Language in Society, 46(4), 547-566. https://doi.org/10.1017/S0047404517000367

Spolsky, B. (2004). Language policy. Cambridge University Press. http://www. cambridge.org

Spolsky, B. (2009). Language management. Cambridge University Press.

Spolsky, B. (2012). What is Language Policy. In S. Bernard (Ed.), The cambridge handbook of language policy (pp. 3-15). Cambridge University Press.

Spradley, J. P. (1979). The ethnographic interview. Holt, Rinehart and Winston.

Steiner, N., \& Hayes, S. L. (2009). Praise for 7 steps to raising a bilingual child. AMACOM.

Szmigiera, M. (2021). The most spoken languages worldwiden 2021. Statista. https://www.statista.com/statistics/266808/the-most-spoken-languagesworldwide/

Tracy, S. J. (2013). Qualitative research methods: Collecting evidence, crafting analysis, communicating impact (3rd ed.). Blackwell.

Wei, L. (2013). Conceptual and methodological issues in bilingualism and multilingualism research. In T. K. Bathia \& W. C. Ritchie (Eds.), The handbook of bilingualism and multilingualism (pp. 26-52). Willey-Blackweel.

Yazan, B., \& Ali, I. (2018). Family language policies in a Libyan immigrant family in the U.S. Heritage Language Journal, 15(3), 369-387. https://doi.org/10.46538/ hlj.15.3.5 